\title{
Novim putovima svile prema održivoj alternativi za umjetnim kožnim materijalima
}

\author{
New silk roads towards to sustainable alternative leather-like materials
}

\author{
Ivana Kovarik Antonović* \\ Zoološki vrt grada Zagreba, Ulica Fakultetsko dobro 1, HR-10000 Zagreb \\ *e-pošta: ivana.kovarik@zoo.hr
}

Stručni rad / Proffesional paper

DOI: $10.34187 / \mathrm{ko} .69 .3-4.4$

\begin{abstract}
Sažetak
Interes za ekološki prihvatljivijim modnim proizvodima znatno se povećao u zadnjih nekoliko godina kao posljedica ozbiljnog narušavanja ekološke ravnoteže uslijed ekološki nepovoljnih proizvodnih procesa. Znanstvenici Sveučilišta Tufts došli su do inovativnih rješenja u proizvodnji umjetne kože. Istraživanja su usmjerili prema biomaterijalu duge povijesti - svili. Proces izrade materijala nalik koži od svilenih vlakana uključuje razgradnju fibroina, temeljnog gradbenog polimera svile, na pojedinačne proteinske komponente u vodenoj otopini, dodatak drugih biopolimera i prirodnih aditiva te računalnu izradu (tehnologija 3D ispisa), koja omogućuje programiranje slojeva i nepravilne geometrijske uzorke. Nastali materijali pokazuju snažne, meke, savitljive, izdržljive i biorazgradive značajke, usporedive s tradicionalnim materijalima za izradu umjetne kože.
\end{abstract}

Ključne rijeći: svila, fibroin, biomaterijali, umjetna koža, održivost

\begin{abstract}
Interest for Eco-Friendly fashion products has increased significantly in recent years, as a result of a serious disturbance of the ecological balance due to harmful production processes. Tufts University scientists have come up with innovative solutions in the production of artificial leather. They have focused on a biomaterial with a long history - silk. The process of making leather-like materials from silk fibers involves the decomposition of silk fibroin protein polymers into individual protein components in a water-based mixture, the introduction of other biopolymers and natural additives and computer fabrication (3D printing technology) that allows layer programming and irregular geometric patterns. The resulting materials show strong, soft, flexible, durable and biodegradable features, comparable to traditional artificial leather materials.
\end{abstract}

Key words: silk, fibroin, biomaterials, alternative leather, sustainability

\section{Uvod}

Modna industrija ima velik utjecaj na okoliš i nije uvijek održiva. Usporedno $\mathrm{s}$ time, $\mathrm{s}$ jedne strane povećava se svijest potrošača o posljedicama koje određeni proizvodi imaju za okoliš, a s druge strane otvaraju se poslovne mogućnosti proizvođačima koji žele proizvoditi po ekološkim načelima [1] Upravo zabrinutost za okoliš i društvo u cjelini dovodi do pojave koncepta „održivog razvoja" koji naglašava potrebu za promicanjem održivosti i zagovara oblik razvoja koji minimizira negativne utjecaje na okoliš i društvo [2]. Društvena odgovornost i okolišna održivost glavna su stajališta filozofije održive mode, a dizajneri koji u njoj stvaraju rade $s$ ciljem kreiranja biorazgradivih proizvoda izrađenih od prirodnih ili recikliranih materijala te upotrebom i korištenjem obnovljivih sirovina. Materijali igraju ključnu ulogu u trenutnom razumijevanju načina na koje mnogi proizvođači, uključujući modnu industriju, mogu doprinijeti održivosti $[3,4]$. Stoga je interes istraživača usmjeren na pronalaženje novih vlaknotvornih biljaka i/ili životinja te lako obnovljivih sirovina za održivu proizvodnju vlakana. Ujedno, takva vlakna moraju imati i visoku stopu biorazgradivosti kako, s obzirom na povećanu potražnju i široko područja primjene, ne bi opteretila okoliš [5].

Obrada i korištenje životinjske kože ubraja se u najstarije ljudske vještine [6]. lako proizvodi izrađeni od kože (poput odjeće, obuće, kožne galanterije, namještaja i ostalog) mogu biti poprilično estetski prihvatljivi i izdržljivi, negativan utjecaj industrije proizvodnje kože na okoliš ozbiljno zabrinjava znanstvenike diljem svijeta. Imajući to na umu, znanstvenici Sveučilišta Tufts, University School of Engineering (SAD), odlučili su pronaći alternativu koži, slične teksture, fleksibilnosti i krutosti, ali izrađenu od materijala koji su održivi, netoksični, lako razgradivi te odgovorni prema okolišu [7]. Pronašli su je u vlaknu tisućljetne povijesti - svili.

\section{Svila}

Baš kao vuna i dlaka, svila je prirodno životinjsko vlakno. Životinjska vlakna su građena od proteina, pa se u osnovi razvrstavaju prema vrsti proteina koja in izgrađuje. Temeljni protein koji izgrađuje svilu naziva se fibroin te se svila stoga još naziva i fibroinsko vlakno. U primjeni je više vrsta vlakana svile, a najveće značenje ima svila koje se dobiva odmatanjem niti s čahure leptira dudova svilca (Bombyx mori L., 1758), čija su vlakna duga i do nekoliko stotina metara. Takva svila najbolje je kvalitete i naziva se plemenita svila, za razliku od svilenih niti koje proizvode gusjenice različitih vrsta leptira prelaca u divljini, pa se takve svile nazivaju divlje svile [8]. Gusjenice leptira prelaca proizvode svilene niti kako bi izgradile čahure koje će im osigurati zaštitu od prijetnji iz okoliša i napada grabežljivaca tijekom procesa njihove preobrazbe.

Uz dvije niti fibroina, gusjenica dudovog svilca izlučuje još jedan protein naziva sericin (Slika 1). Sericin, koji čini oko $25 \%$ svilene mase jedne čahure, pritom ima ulogu ljepila te sljepljuje dvije fibroinske niti $u$ jednu čvrstu nit koja na zraku očvrsne i osigurava kompaktnost svilene čahure. Sericin se mora ukloniti s fibroina u postupku degumiranja sirove svile u blago alkalnim sapunskim otopinama. Uzgoj dudovog svilca i odvajanje niti sa svilene čahure vještina je stara više tisućljeća, dio je svjetske baštine, a u biti se svila na gotovo nepromijenjen način i dan danas proizvodi [8]. No, inženjeri Sveučilišta Tufts uspjeli su razgraditi vlakna iz čahura dudova svilca na njihove komponente te in uz pomoć kombinirane mješavine biomaterijala ponovno uobličiti u materijal nalik koži.

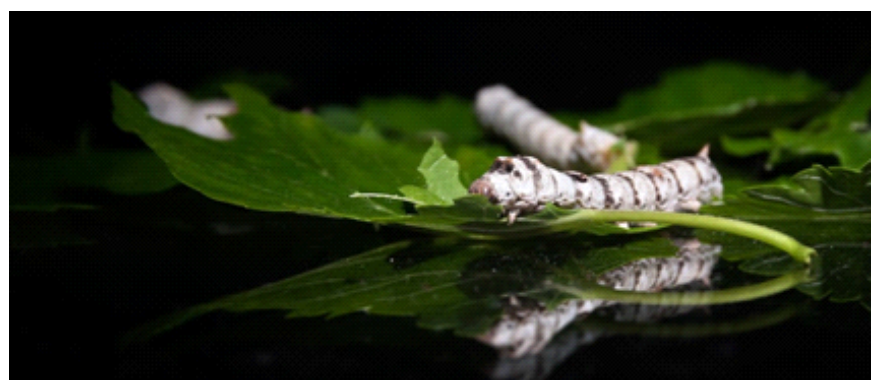

Slika 1. Hranjenje gusjenica dudova svilca (Bombxy mori L., 1758) lišćem bijelog duda u Zoološkom vrtu grada Zagreba. Fotografija: Matija Dronjić. Viši kustos, voditelj Audiovizualnih fondova Etnografskog muzeja u Zagrebu. 


\subsection{Serikultura - proizvodnja svile}

Svilene čahure dudova svilca (Bombyx mori L., 1758) su vrijedna tržišna roba koja se koristi već stotinama godina za proizvodnju tekstila i kirurškog konca u medicini [9]. Svila je pojam prestiža, udobnosti i prirodnosti, no njena proizvodnja nije uvijek ekološki i etički prihvatljiva. Naime, tijekom posljednje faze metamorfoze, leptir ispušta proteolitički enzim kokonazu koji otapa čahuru na jednom kraju, prekidajući svilenu nit i omogućava neometani izlazak odraslog leptira (Slika 2). Stoga, kako bismo dobili dugačke i neprekinute svilene niti, metamorfoza gusjenice mora se prekinuti u pravom trenutku, što se najčešće postiže djelovanjem vodene pare ili namakanjem čahura u vrućoj vodi ili zamrzavanjem. No, takav način proizvodnje svile nije u skladu s konceptom održivosti i načelima dobrobiti prema živim bićima. Ahimsa svila, odnosno „svila mira“, predstavlja svilu proizvedenu na način da se omogući leptiru da dovrši svoju preobrazbu i izađe iz čahure [10]. Upotrebljavajući isključivo napuštene svilene čahure za proizvodnju svile, proizvođači poštuju načela dobrobiti životinja te iskorištavaju prirodne nusproizvode, što je u konačnici ekološki i etički prihvatljivo te bi trebalo biti imperativ u serikulturi.

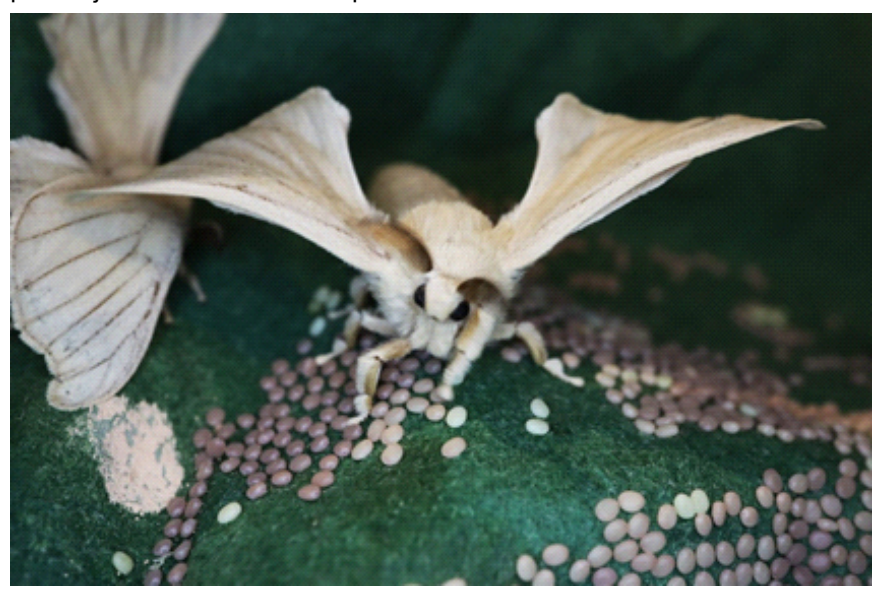

Slika 2. Leptir dudova svilca (Bombxy mori L., 1758) pri polaganju jajašaca. Fotografija: izv. prof. Helena Schultheis Edgeler, prof. likovne kulture. Sveučilište u Zagrebu Tekstilno-tehnološki fakultet; Zavod za dizajn tekstila i odjeće.

\section{Proizvodnja umjetne kože od biomaterijala}

Kompoziti biomaterijala na bazi preformuliranog proteina svile nude nove puteve za čvrste i stabilne, ekološki prihvatljive materijale nalik koži izravno dobivene iz svilenih čahura [7]. Istraživanja o netoksičnim, nezagađujućim, potpuno reciklirajućim sredstvima za obradu i proizvodnju u industriji kože mogu uvelike pridonijeti smanjenju negativnog utjecaja na okoliš [3]. Preradba sirovih životinjskih koža, kao i proizvodnja umjetne kože, ne odvija se bez štetnih posljedica za okoliš [4, 11], a trenutni trendovi takozvane „zelene“ proizvodnje vode se strategijama poput smanjene upotrebe štetnih kemikalija koje se koriste u preradi materijala [11], korištenja obnovljivih materijala [3], prirodnih boja, neštetnih procesa štavljenja [11] te korištenja umjetne kože proizvedene od nusproizvoda ili recikliranih materijala $[4,11]$. Zanimljivo je da se obnovljivi biomaterijali poput celuloze, hitina ili svile, prirodno i u izobilju proizvode od strane biljnih i životinjskih organizama, a mogu se dobiti i izolacijom iz industrijskih nusproizvoda (npr. ljušture školjkaša i rakova, otpadni drvenasti materijal lišće biljaka, napuštene svilene čahure leptira iz porodice prelaca). Njihova obrada u otopini vode ne zagađuje okoliš, a njihov kemijski sastav omogućuje kompatibilnost s netoksičnim bojilima [12]. Njihova mehanička svojstva i udobnost su još u fazi izučavanja, ali neki početni rezultati obećavaju održive alternative tradicionalnoj proizvodnji kože [7].

\subsection{Proces izrade materijala nalik koži od svilenih vlakana dudova svilca (Bombyx mori L., 1758)}

Danas se fibroin iz svile može izolirati iz napuštenih svilenih čahura, regenerirati uz definirani stupanj polimerizacije i iz vodene otopine preobličiti raznim, analognim i/ili digitalnim metodama izrade u različite oblike kao što su tanki filmovi i prevlake, vlakna, mikroporozne membrane, pređe, spužve ili gotovi uporabni predmeti [7]. Postupak regeneracije polimera provodi se sol-gel postupkom koji obuhvaća reakcije hidrolize i kondenzacije metalnih alkoksida pri čemu nastaje neprekinuta trodimenzijska metaloksidna mreža [13]. To je jedan od najjednostavnijih načina za dobivanje modificiranih materijala sa željenim svojstvima [14], pri čemu se metastabilne krutine nastale kinetički kontroliranom reakcijom iz molekularnih prekursora koriste kao gradbeni materijal za daljnju preradu [15].

Na taj način su inženjeri Sveučilišta Tufts proizveli materijale nalik koži koji nude neke jedinstvene prednosti u odnosu na druge pristupe u proizvodnji umjetne kože, a njihova izrada se temelji na korištenju svilenih vlakana tehnologije $3 \mathrm{D}$ ispisa. Ova tehnologija pruža mogućnost stvaranja više redova mikro-uzoraka koji mogu prilagoditi snagu i fleksibilnost materijala te mogućnost ispisivanja makro-uzoraka koji bi oponašali površinsku teksturu prirodne kože [7]. Dobiveni materijal ima slična fizikalna svojstva kao prirodna koža, može izdržati savijanje, bušenje i istezanje kojem se obično izlažu materijali za izradu galanterije, uključujući mogućnost spajanja komada materijala i pričvršćivanja dodataka kao što su zakovice, ručke i kopče [7] (slika 3). Bitno je naglasiti da je takav materijal u potpunosti biorazgradiv, što ga čini ekološki prihvatljivim za okoliš. Nadalje, kožnati proizvodi od regenerirane svile imaju mogućnost ponovnog otapanja i stvaranja reciklirane materije nalik gelu za ponovljenu proizvodnju ili se mogu na primjeren način ukloniti iz uporabe jer su u potpunosti biorazgradivi [7]

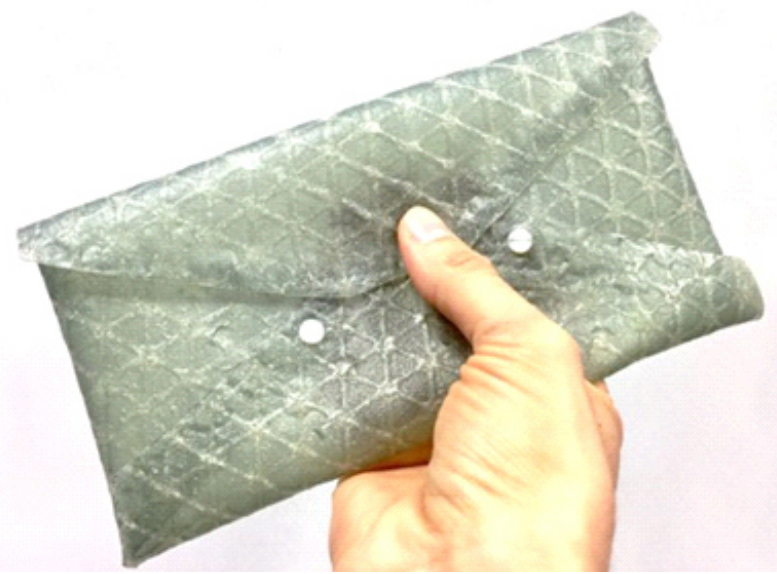

Slika 3. Mala ručna torbica (engl. Clutch) izrađena od regenerata svilenih vlakana. Fotografija preuzeta s: https://now.tufts.edu/news-releases/tuftssilklab-creates-leather-material-silk-proteins, uz dopuštenje autora. Pristupljeno: 2021-18-11

Pri 3D ispisu se, osnovni sloj konstrukcijskog materijala koji se sastoji od hitozana $u$ vodenoj otopini octene kiseline $u$ kombinaciji $s$ netoksičnim plastifikatorom kao što su glicerol i termokromne boje, trodimenzionalno ispisuje kao početni sloj kako bi se osigurala fleksibilnost i čvrstoća dobivenog materijala [7]. Strukturni sloj na površini osnovnog, sastoji se vodene otopine fibroina svile u kombinaciji s plastifikatorom (glicerol) i prirodnog biljnog zgušnjivača (natrijev alginat), čime se osigurava krutost $i$ vlačna čvrstoća [7] (Slika 4.). Ekstrudiranjem fibroinske otopine kroz mlaznicu pisača stvaraju se posmične sile koje mogu doprinijeti rasporedu proteina na način koji osnažuje materijal, čineći ga duktilnim, a ne krhkim, čime se ujedno oponaša i prirodno istiskivanje nalik onom iz svileni žlijezdi leptira pelaca ili paučnjaka [7]. Promjenom tiskanog uzorka svilenog sloja može se promijeniti izgled materijala, podesiti čvrstoća, ali i druge fizikalne karakteristike [7]. Koristeći ekstrudiranu fibroinsku otopinu s dodanim biomaterijalima i primjenom tehnika očvršćivanja mogli bi se smanjiti, ako ne i ukloniti problemi koji karakteriziraju tradicionalnu proizvodnju kože, poput pretjeranog iskorištavanja izvora sirovina, velike potrošnje energije, emisije toksičnih plinova, korištenja sulfida, natrijevog klorida, kromnih soli, vapna i ostalih anorganskih tvari koje dospijevaju u površinske vode [4, 16].

Tijekom posljednjeg desetljeća, područje znanosti o materijalima postiglo je veliki napredak u reverznom inženjeringu svilenih vlakana u vodenu otopinu proteina svile, nalik onom prirodnom stanju koji se nalazi unutar svilenih žlijezda kukaca iz porodice prelaca $[17,18,19]$. lako postoji mnogo opcija za materijale nalik koži, koža na osnovi svile ima potencijal da bude najpodložnija inovativnom dizajnu [7]. 
[5] Pernar J., Vujasinović E.: Biorazgradiva i održiva vlakna, Tekstil: časopis za tekstilnu i odjevnu tehnologiju 67 (2018.) 9-10,

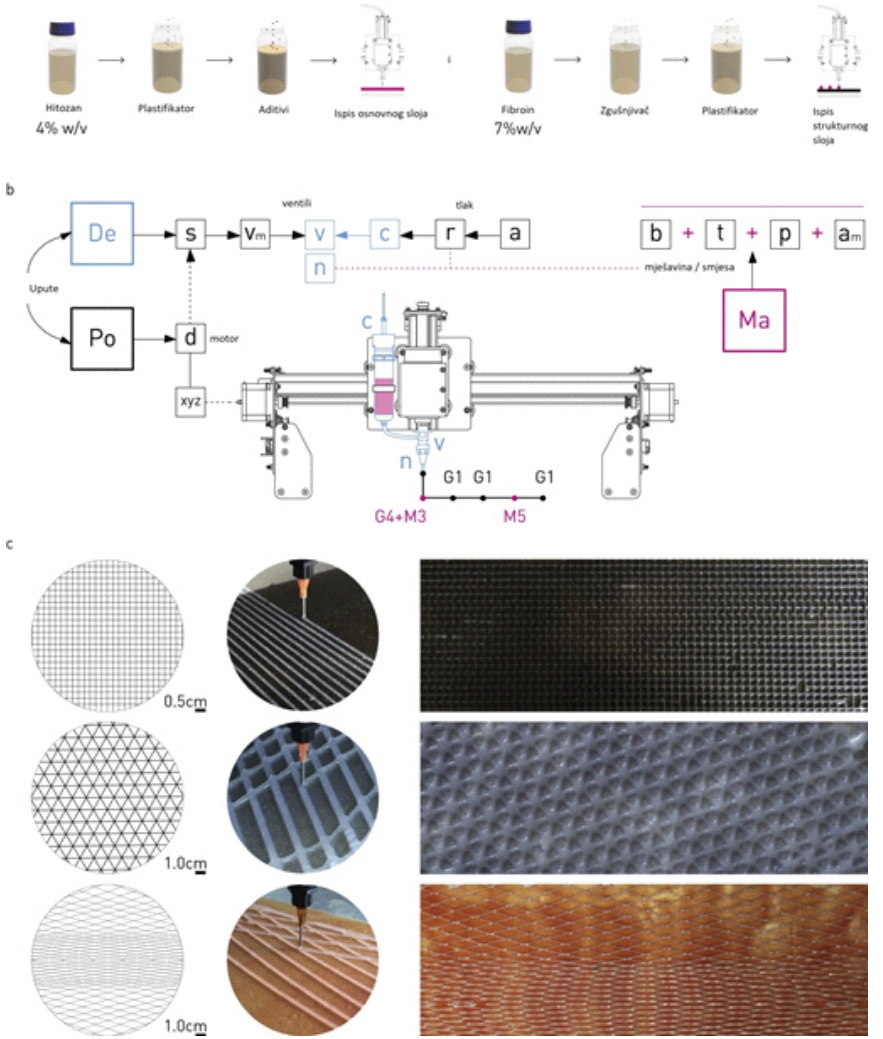

Slika 4. Tehnologija 3D ispisa koja omogućuje programiranje slojeva nepravilne geometrijske uzorke. Preuzeto i prilagođeno prema MogasSoldevila L. et al. (2021) [7].

\section{Zaključak}

Inženjeri Sveučilišta Tufts proizveli su materijale nalik koži od svilenih vlakana napuštenih čahura dudova svilca (Bombxy mori L., 1758.) te među literaturom za sada pronalazimo jedini takav primjer u pristupu proizvodnji umjetnih kožnih materijala. Posljednjih godina tzv. „zelena“, odnosno biorazgradiva vlakna, postala su ekološki imperativ u tehnološkim postupcima proizvodnje modne industrije. Osim biorazgradivosti, karakterizira in i minimalna potrošnja energije prilikom obrade. Istovremeno, sve se više potiče serikultura vođena etičkim načelima uzgoja sviloprelaca, odnosno proizvodnja svilenih vlakana od napuštenih svilenih čahura. Mnogi proizvođači "zelene“ modne industrije, vođeni načelima održivog razvoja, iskazuju potrebu za alternativnim izvorima sirovina. Proizvodnja i primjena vlakana dobivenih iz nekonvencionalnih izvora, poput vlakana divlje svile od napuštenih čahura sviloprelaca iz divljine, otvaraju nove mogućnosti iskorištavanja prirodnih izvora koji su istovremeno ekološki i društveno prihvatljivi. Velik dio istraživanja vlakana mnogih vrsta divlje svile posvećen je ispitivanju različitih svojstava njihovih vlakana usporedno sa svojstvima svilenih vlakana dudova svilca, no međutim samo kao alternativan izvor tekstilnog biomaterijala.

\section{Literatura}

[1] Gam H.J. et al: Quest for the eco-apparel market: a study of mothers' willingness to purchase organic cotton clothing for their children, International Journal of Consumer Studies, 3 (2010) 6 , $648-656$

[2] Joshi Y., Rahman Z.: Factors Affecting Green Purchase Behaviour and Future Research Directions, International Strategic Management Review, 3 (2015) 1-2, 128-143

[3] Fletcher K.: Sustainable Fashion and Textiles, Routledge 2014

[4] Giljum S. et al: Global Patterns of Material Flows and their Socio-Economic and Environmental Implications: A MFA Study on All Countries World-Wide from 1980 to 2009, Resources 3 (2014) 1, 319-339 258-278

[6] Reed R.: Science for students of leather technology, Pergamon Press Ltd. 1966, 134-138

[7] Mogas-Soldevila L. et al: Additively manufactured leather-like silk protein materials, Materials \& Design 203 (2021) https://doi.org/ 10.1016/j.matdes.2021.109631.

[8] Čunko R., Andrassy M.: Vlakna, Zrinski d.d, 2005., 170-178

[9] Omenetto F.G., Kaplan D.L.: New Opportunities for an Ancient Material, Science 329 (2010) 5991, 528-531

[10] Sanapapamma K.J., Naik S.D.: Contemporary breakthrough in Ahimsa silk spinning, Indian Journal of Traditional Knowledge 7 (2008), 178-181

[11] Chen H.L., Burns L.D.: Environmental Analysis of Textile Products, Clothing and Textiles Research Journal 24 (2006), 248-261

[12] Hu X.: A field-based test of burial dating using cosmogenic isotopes: Fluvial terraces along the Yellow River, Lanzhou, China, Quaternary International 11 (2012), 279-280

[13] Macan J.: Sol-gel postupak za pripravu organsko-anorganskih hibridnih materijala, Kemija u industriji : Časopis kemičara i kemijskih inženjera Hrvatske 57 (2008.), 355-361

[14] Morosanova E. I.: Silica andsilica-titaniasol-gelmaterials: Synthesis and Analytical Applications, Journal of Analytical Chemistry 73 (2018), 1043-1052

[15] Schubert U.: The Sol-Gel Handbook: Synthesis, Characterization, and Applications, Wiley-VCH Verlag GmbH \& Co. KGaA., 2015

[16] Tao H. et al: Silk Materials - A Road to Sustainable High Technology, Advanced Materials 24 (2012), 2824-2837

[17] Jin H.-J., Kaplan D.L.: Mechanism of silk processing in insects and spiders, Nature 424 (2003), 1057-1061

[18] Omenetto F.G., Kaplan D.L.: A new route for silk, Nature Photonics, 2 (2008), 641-643

[19] Omenetto F.G., Kaplan D.L.: From silk cocoon medical miracle. Scientists are crafting arteries, ligaments, circuitry and holograms from worm yarn, Scientific American 303 (2010), 76-77 